\title{
GEOCHEMICAL AND Pb ISOTOPIC SIGNATURE OF PEATY SEDIMENTS FROM CENTRAL-SOUTH CHILE: IDENTIFICATION OF PARTICLE SUPPLIES OVER THE HOLOCENE
}

\author{
FRANÇOIS DE VLEESCHOUWER ${ }^{*}$, MAUD IBANEZ ${ }^{2}$, NADINE MATTIELLI ${ }^{2}$, CLAUDE MAERSCHALK ${ }^{2}$ \\ AND NATHALIE FAGEL ${ }^{1}$
}

\begin{abstract}
${ }^{1}$ Unité de Recherche Argiles et Paléoclimats, Département de Géologie, Université de Liège, Belgium
${ }^{2}$ Département des Sciences de la Terre et de l'Environnement, Université Libre de Bruxelles, Belgium (Received: August 16, 2007 - Accepted: March 17, 2008)
\end{abstract}

\begin{abstract}
Two cores from tephra rich peat soils of the Chilean Lake District were investigated for mineral source and potential anthropogenic impact using elemental geochemistry, including rare earth elements, and lead isotopes. The dominant particle source to the area are the Trumaos which are the local ando soils derived from the weathering of volcanic deposits. In Galletué, although short term events of enhanced particle inputs occur, elemental and isotopic signatures show that the Trumaos are the only particle source to the area. In San Pablo de Tregua, punctual events of crustal particle inputs are recorded in Pb enrichment factors and isotopic profiles, reflecting a long range crustal involvement. This site also records the inception of the anthropogenic in the area in recent samples of which $\mathrm{Pb}$ enrichment factors and lead isotopic signatures shift drastically.
\end{abstract}

Keywords: Peat soil, Trace elements, Pb isotopes, Ando soils, Lake District, Chile, Holocene

\section{INTRODUCTION}

During the last decade, many researches have been focused on peat cores as archives of atmospheric deposition, providing important data on palaeoclimatic and anthropogenic history ${ }^{1-5}$. Recent studies have for example demonstrated that ombrotrophic peat (i.e. exclusively fed by atmospheric deposition) is an excellent archive to record $\mathrm{Pb}$ atmospheric history throughout the Holocene $\mathrm{e}^{4,6}$.

Studies of past atmospheric deposition are more rare in minerotrophic peat despite a common occurrence relative to ombrotrophic bogs. This is principally due to possible mobilization of elements linked to the fluctuation of watertable, or leaching by groundwater ${ }^{7,8}$. However other authors ${ }^{9-13}$ have demonstrated the potential of mineralotrophic peat to record past climatic or anthropogenic changes.

In Southern Hemisphere, very few articles have investigated Holocene or anthropocene reconstruction derived from peat bog geochemistry ${ }^{14-17}$. There are however numerous geochemical data from several sites of the Antarctic ice cap $^{18-20}$ are available and could be useful to decipher sources of particles and/or periods of pollution.

In this study, we focus on minerotrophic peat soils from the Chilean Lake District (Meridional Chile, $38-40^{\circ} \mathrm{S}$ ). In an attempt to identify the main particle source (average Upper Continental Crust, mean Chilean Southern Volcanic Zone, and Trumaos, anthropogenic source), this study aims to decipher between local and global influence on peat records, using the depth evolution of geochemical and $\mathrm{Pb}$ isotopic compositions of peat soils.

\section{MATERIAL AND METHODS}

Site description

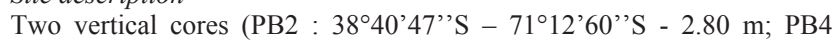
: $39^{\circ} 35^{\prime} 20^{\prime \prime} \mathrm{S}-71^{\circ} 03^{\prime} 78^{\prime \prime} \mathrm{W}-4.00 \mathrm{~m}$ ) were drilled in peat soils from the Chilean Lake District (Fig. 1). The cores were retrieved using a Belorussiantype stainless steel D-corer ${ }^{21,22}$. Semi-cylindrical core are $50 \mathrm{~cm}$ long and 4.5 $\mathrm{cm}$ in diameter were sampled and bagged into PVC tubes and then wrapped in plastic. A pre-coring was performed to locate the thickest sediment accumulation.

The Chilean Lake District is located at the feet of the Andes, between $38^{\circ} \mathrm{S}$ and $42^{\circ} \mathrm{S}$. The lakes are the results of the retreat of the Andean glaciers during the Late Glacial-Holocene transition ${ }^{23-26}$. This glacial landscape provides several peat infillings. This region, part of the Chilean Southern Volcanic Zone (SVZ), has been repeatedly under volcanic activity during the Holocene. Tephras were deposited from surrounding complex active volcanoes such as the Llaima, Lonquimay, Villarrica or Mocho-Choschuenco volcanoes ${ }^{27}$. The entire area is covered by 4 to $6 \mathrm{~m}$ thick andosoils formed by volcanic ash accumulation and weathering ${ }^{28,29}$, locally called Trumaos (Fig. 1). These Trumaos provide a large amount of local mineral particles that could be transported by wind action and trapped by peat soils.
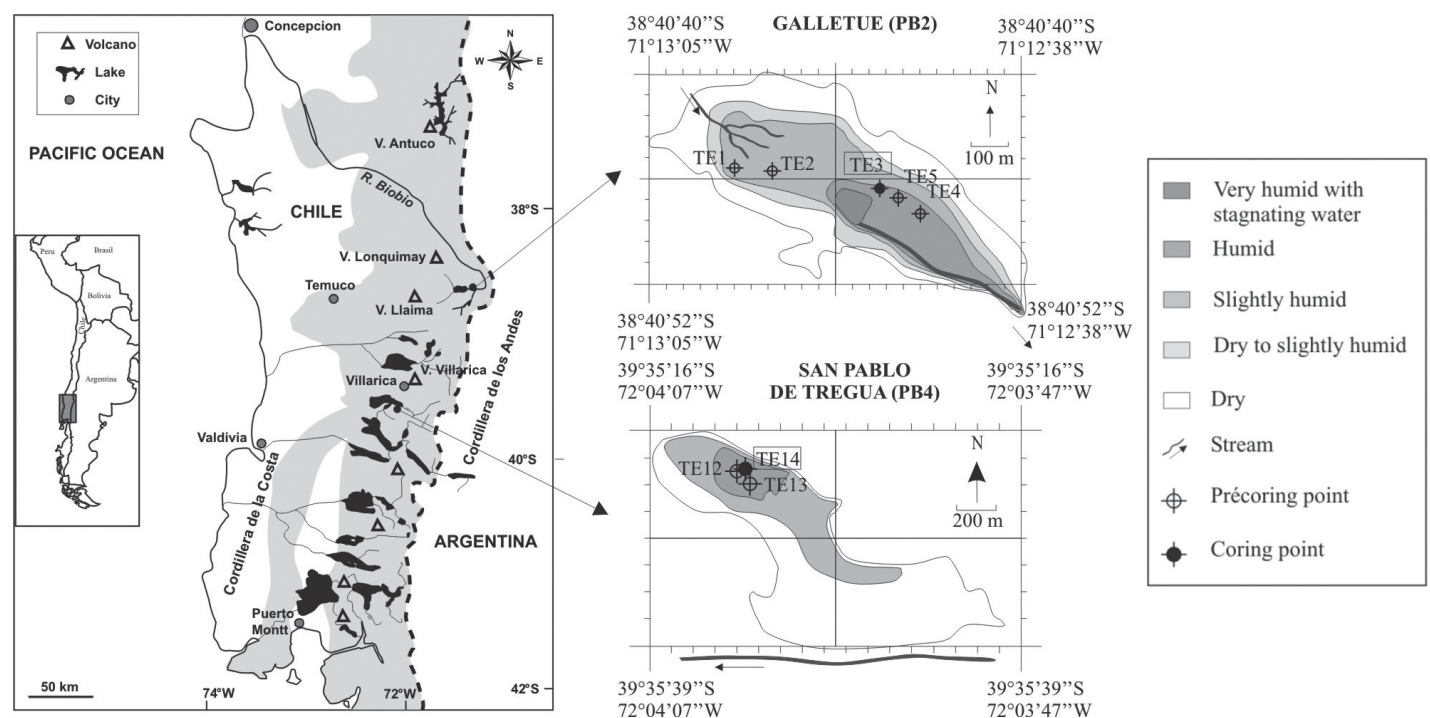

Figure 1. Locations of the two sites in the lake district map ${ }^{29}$, and surface humidity zones. Grey shaded zone on the left map shows the extension of Andosoils, locally called Trumaos (reported from FAO-UNESCO). 
In Galletué peat soil (PB2), vegetation is mainly composed of Juncus sp., Carex spp., a few Sphagnum spp., and several species of Gramineae ${ }^{30}$. In San Pablo de Tregua (PB4), Sphagnum spp. becomes abundant in the uppermost peat layers $(20 \mathrm{~cm})$. The actual vegetation of this mire presents an important cover of Carex spp. and Gramineae spp. Shrubs species like Escallonia alpina, Baccharis sp. ${ }^{31}$ and Chusquea spp. are also present, indicating a drying of the area. Both sites are fed by several little streams providing a non-atmospheric contribution to the peat soils.

\section{${ }^{14} \mathrm{C}$ dating}

Two samples from PB2 and four from PB4 have been dated either by AMS at Poznan Radiocarbon Institute (Poland), and by conventional (i.e. $\beta$ counting) technique at Centre for Isotope Research, University of Gröningen (The Netherlands). Results are reported in Table 1. Sediment accumulation covers more than 8500 years in PB2 and more than 11000 years in PB4.

Table 1. AMS (Poz samples) and conventional (GR samples) dating and associated Oxcal $3.8^{32}$ calibrated ages from samples from PB2 and PB4. * depth dated by tephra correlation of a dated sampwle in a neighboring outcrop.

\begin{tabular}{|c|c|c|c|c|c|}
\hline Site & Sample & Depth & Age yr B.P. & Error & Age ranges \\
\hline & number & $\mathbf{( c m )}$ & & & yr cal B.P. \\
\hline & & & & & \\
\hline PB2 & & & & & \\
\hline & Poz-252 & $* 120.5$ & 2900 & \pm 45 & $2920-3170$ \\
\hline & GrN-27083 & 282.5 & 7350 & \pm 200 & $7750-8550$ \\
\hline & & & & & \\
\hline PB4 & & & & & \pm 30 \\
\hline & Poz-6863 & 45 & 645 & $550-670$ \\
\hline & Poz-1320 & 90 & 3970 & \pm 50 & $4250-4540$ \\
\hline & Poz-1319 & 190 & 7490 & \pm 40 & $8180-8380$ \\
\hline & GrN-27085 & 340 & 9480 & \pm 160 & $10250-11200$ \\
\hline
\end{tabular}

\section{Sediment characterization}

High resolution magnetic susceptibility (HRSM), bulk density and total organic carbon (Fig. 2) were measured in both peat cores to detect specific lithologies that could induce geochemical fluctuations. HR-magnetic susceptibility was measured every $5 \mathrm{~mm}$ using an MS2 Magnetic Susceptibility System equipped with a MS2E spot-reading sensor (Bartington Instruments). Measurements were duplicated to assess reproducibility. HRSM exhibits sharp peaks when fine tephras are present. When tephras are coarser, their porosity prevents good contact between the sensor and the core. Recorded values represent in this case an underestimation of the real magnetic field. Additional HRSM fluctuations are rather due to other lithological variations. Bulk density is estimated by weighting a $1 \mathrm{~cm}$ thick semi-cylinder of sediment preliminary dried at $105^{\circ} \mathrm{C}$ for $12 \mathrm{~h}$. Total organic carbon was measured with a CS-200 Leco analyzer (CBR Harmignies, Belgium) on dried $\left(105^{\circ} \mathrm{C}, 12 \mathrm{~h}\right)$ and milled samples. Errors on $\mathrm{C}_{\text {org }}$ measurements range from 5 to $10 \%$.

\section{Preparation and acid digestion of peat samples}

Samples were taken out from the core using $5 \mathrm{ml}$ acid cleaned plastic tools. Only the central part of the semi-cylinder sampled. Samples were dried $\left(105^{\circ}\right.$ for $12 \mathrm{~h}$ ) and milled using an agate mortar. The sampling was constrained by the numerous tephra falls along the profiles and remained therefore irregular and quite large (sampling resolution up to 1 sample $/ 40 \mathrm{~cm}$ ).

All the samples were processed in clean air cabinets (ULB, Belgium). Digestion consisted in a two-step acid dissolution in closed Savilex ${ }^{\circledR}$ beakers: (1) organic matter is digested by repeated addition of $\mathrm{H}_{2} \mathrm{O}_{2} 30 \%$ p.a. and $\mathrm{HNO}_{3}$ $65 \% c c$. sub. in a proportion of $3: 1 ;(2)$ mineral matrix is then digested by addition of $\mathrm{HF}$ suprapur (Merck) $+\mathrm{HNO}_{3} 65 \%$ cc. sub. $\pm \mathrm{HClO}_{4}$ in a proportion of $1: 6: 0.5$. The beakers were placed on a hot plate at $130^{\circ} \mathrm{C}$ for 4 days. After drying, $6 \mathrm{~N} \mathrm{HCl}$ was added and slowly evaporated.

\section{Elemental geochemistry}

Elemental geochemistry was measured using ICP-AES (IRIS Advantage) for major and transition elements and ICP-MS (VG PlasmaQuad PQ2) for trace elements at MRAC-Tervuren (Belgium). Si could not be analysed because of $\mathrm{SiF}_{4}$ volatilisation during the $\mathrm{HF}-\mathrm{HNO}_{3}$ digestion procedure. Calibrations were made with In-Ru-Re-Bi internal standards ( 10 and $20 \mathrm{ppb}$ ), and two international reference materials: BCR CRM-100 beech leaves (EU certificated) and granite $\mathrm{GA}^{33}$, chosen to be representative of the current soil and volcanic samples. Accuracy varied between $1-11 \%$ for major elements, $1-2 \%$ for transition metals and $1-5 \%$ for other trace elements. Detection limits (i.e. mean $+3 \sigma)$ were lower than $1 \mathrm{ppm}$ for major elements excepted $\mathrm{Na}(2.7 \mathrm{ppm}), \mathrm{K}(1.1 \mathrm{ppm})$ and $\mathrm{P}$ (7.9 $\mathrm{ppm})$. Detection limits for trace metals and other trace elements were lower than 1 and $10 \mathrm{ppb}$, respectively. To assess sample heterogeneity, replicates from both cores were analysed (PB2 $-108 \mathrm{~cm}$, PB4 $-310 \mathrm{~cm}$ ). Results for replicates are comparable within errors to the original analyses.

\section{Lead isotope signatures}

Lead fraction was separated using a one step ion-exchange chromatography on AG1-X8 resin following previouly reported chemical procedures ${ }^{34}$. To monitor instrumental mass bias, Tl was added to each sample to achieve a $\mathrm{Pb} / \mathrm{Tl}$ of $=5$ and thus match the $\mathrm{Pb} / \mathrm{Tl}$ ratio of the standard. During the analysis sessions, measurement of NBS $981 \mathrm{~Pb}$ standard was systematically performed after every two samples. It gave average individual error $(2 \sigma, 95 \%$ confidence $)$ on $\mathrm{Pb}$ isotopic analyses for Galletué (PB2) and rock samples of 0.0200 for ${ }^{208} \mathrm{~Pb} /{ }^{204} \mathrm{~Pb}, 0.0150$ for ${ }^{207} \mathrm{~Pb} /{ }^{204} \mathrm{~Pb}$ and 0.0180 for ${ }^{206} \mathrm{~Pb} /{ }^{204} \mathrm{~Pb}$ (for more details see Table 4). Acids were distilled $\left(\mathrm{HNO}_{3}\right)$ or sub-boiled $(\mathrm{HF}, \mathrm{HCl}, \mathrm{HBr}) . \mathrm{Pb}$ total blanks for the whole procedure range between 40pg and 200pg. This is negligible relative to $\mathrm{Pb}$ contents in the samples $(150 \mathrm{ng}<\mathrm{PB} 2$ content $<$ 900ng, 25ng $<$ PB4 content $<8.3 \mu \mathrm{g}$ ).

Lead isotopic ratios were measured on Nu-Plasma MC-ICP-MS (ULB, Belgium) during three analysis sessions. All the standard values of this study fall in these ranges. Internal laboratory reproducibility are $0.027 \mathrm{for}{ }^{206} \mathrm{~Pb} /{ }^{204} \mathrm{~Pb}$, 0.026 for ${ }^{207} \mathrm{~Pb} / 204 \mathrm{~Pb}, 0.003$ for ${ }^{208} \mathrm{~Pb} /{ }^{204} \mathrm{~Pb}, 0.1$ for ${ }^{207} \mathrm{~Pb} /{ }^{206} \mathrm{~Pb}$ and 0.15 for ${ }^{208} \mathrm{~Pb} /{ }^{206} \mathrm{~Pb}(\mathrm{n} \sim 600,2 \sigma$ level, $95 \%$ confidence) after several years of analyses. The total $\mathrm{Pb}$ beam intensities varied from 4 to $10 \mathrm{~V}$. Intensities during analyses of San Pablo de Tregua were sometimes lower $(<1 \mathrm{~V})$, explaining the larger average individual errors for those samples. A duplicate of the whole procedure (i.e. including dissolution, column exchange and analysis) on a PB2 sample (108 cm depth) was also analysed. The sample and the replicate results show differences of $13 \times 10^{-3}$ for ${ }^{206} \mathrm{~Pb} / 204 \mathrm{~Pb}, 36 \times 10^{-5}$ for ${ }^{207} \mathrm{~Pb} /{ }^{206} \mathrm{~Pb}$ and $87 \times 10^{-7}$ for ${ }^{208} \mathrm{~Pb} / 206 \mathrm{~Pb}$.

\section{Selection of the reference element}

Comparable profiles of major element concentrations variations as a function of depth suggest an important imprint of the soil lithology. To compensate for the influence of the lithology or matrix effect, trace and major element concentration values have been normalized. The peat soils of this study are located in a volcanic environment. Therefore the regional noncrustal geology of the Chilean Lake District has to be taken into account. Ti, $\mathrm{Al}, \mathrm{Zr}$, or $\mathrm{Y}$ are lithophile elements, well known for their resistance against weathering ${ }^{35,36}$. They are common in several minerals found in volcanic falls, such as, for example, glass shards (Al, Ti), plagioclase (Al), titanite (Ti), ilmenite (Ti), titano-magnetite (Ti), zircon $(\mathrm{Zr}) . \mathrm{Zr}$ and $\mathrm{Y}$ have been often used in literature ${ }^{10}$ as reference elements, but they are in this study sometimes under detection limit. In contrast $\mathrm{Al}$ appears to be the most abundant element the samples. A slight fluctuation in [Al] will therefore strongly influence the fluctuation in the corresponding [trace element]/[Al] ratio. Consequently, $\mathrm{Ti}$, a conservative element ${ }^{35}$ moderately abundant in several resistant volcanic mineral phases, is chosen as the reference element. We assume in the studied area an almost entire Ti supply provided by weathering products of the SVZ volcanism (i.e. Trumaos). Because such a soft material is easily transported by wind, it is the most suitable source of particles in this area. Ti flux is obtained using the following formula ${ }^{10}$ :

Ti Flux $=[\mathrm{Ti}]_{\text {sample }} \mathrm{x}($ density $) \mathrm{x}($ accumulation rate $)$,

Total particle flux is calculated as follows :

$\mathrm{TPF}=\mathrm{Ti}$ Flux $\mathrm{x}$ 100/[Ti (\%) $]_{\text {}}$

$\mathrm{Pb}$ enrichment factors are calculated using the formula ${ }^{37}$ :

E.F. $(\mathrm{Pb})=\left([\mathrm{Pb}]_{\text {sample }} /[\mathrm{Ti}]_{\text {sample }}\right) /\left([\mathrm{Pb}]_{\text {Trumaos }} /[\mathrm{Ti}]_{\text {Trumaos }}\right)$ 


\section{RESULTS}

\section{Lithology}

The lithology of both cores is strongly influenced by weathering products from SVZ as the mineral residue of the samples is exclusively composed of volcanic minerals (e.g. plagioclase, pyroxene, olivine) and glass shards. Both peat soils were repeatedly blanketed by tephra falls up to $10 \mathrm{~cm}$ thick. These observations are consistent with the minerotrophic character of the two sites.

PB2 shows a low organic carbon content (mean $\mathrm{C}_{\text {org }}=5.4 \%$ ) and high density values (mean $\left.\delta=0.6\right)$. A peak in density $(\delta=0.91)$ at $90 \mathrm{~cm}$ is correlated with a rapid decrease of the total organic carbon content $\left(\mathrm{C}_{\mathrm{org}}^{\stackrel{\mathrm{org}}{=}} 2.73 \%\right)$ and a slight positive shift in HRSM. This shift is not due to a tephra layer (as the nearest tephra is at $95 \mathrm{~cm}$ depth), but to a strong clayey and mineral-rich layer (Fig. 2). Below total organic carbon is very low and density is high, reflecting the strong minerogenic character of the sediment. This mineral character becomes more important under $250 \mathrm{~cm}$ depth as HRSM increases significantly.

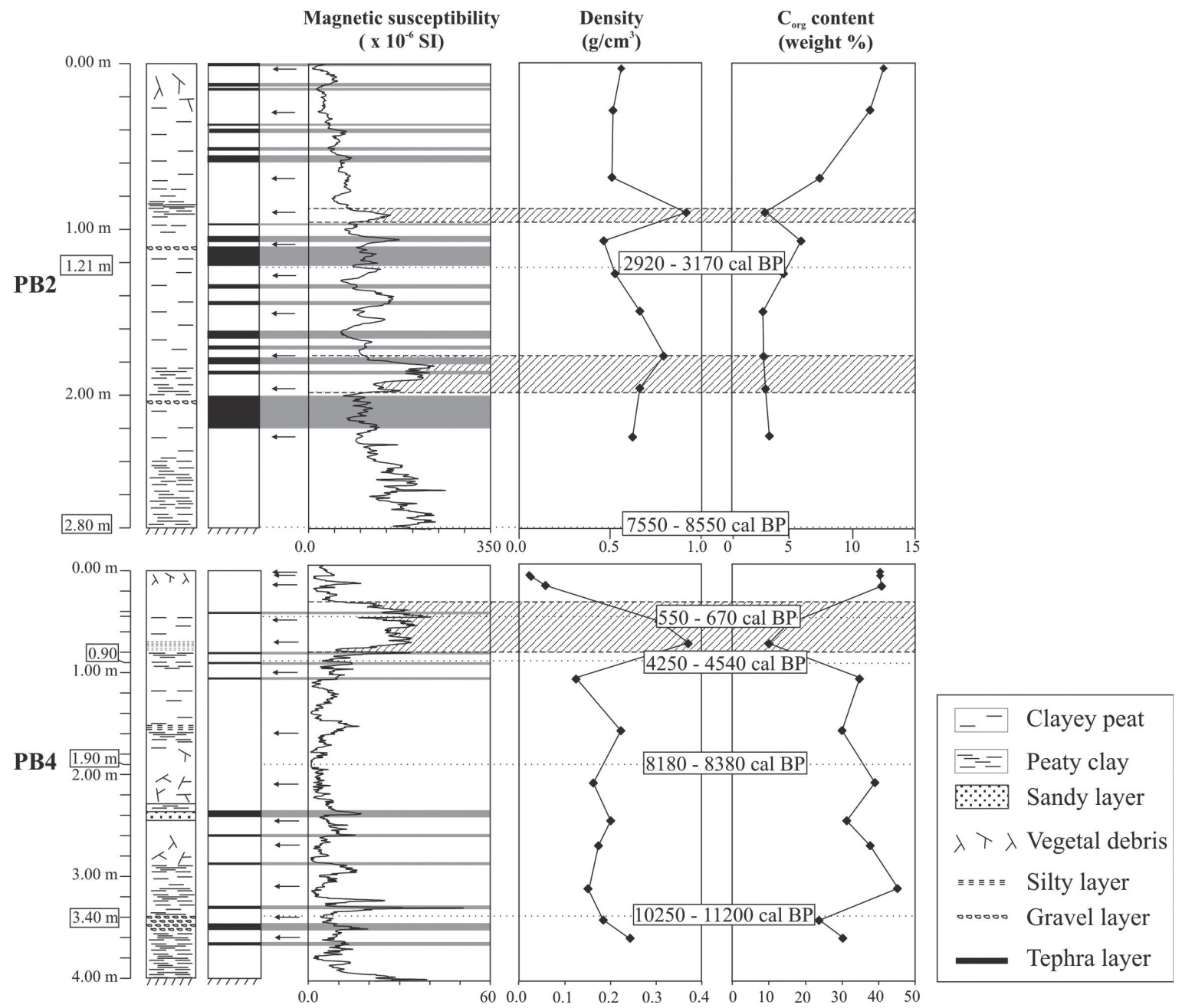

Figure 2. Lithological (left $\log$ ) and tephrostratigraphical (right $\log$ ) columns. In parallel are shown high resolution magnetic susceptibility dry bulk density and organic carbon content curves. Arrows indicate samples depth. ${ }^{14} \mathrm{C}$ calibrated ${ }^{32}$ ages are also reported.

In contrast, PB4 displays an average higher total organic carbon content (mean $\mathrm{C}_{\text {org }}=31.7 \%$ ) and lower density (mean $\delta=0.2$ ) values relative to PB2. HRSM is also very low (always under $50 \times 10^{-6} \mathrm{SI}$ ). This could reflect the lower contents of tephras and/or mineral particles in PB4. In this core, the Sphagnumdominated layers become increasingly mineralised from 0 to $70 \mathrm{~cm}$ depth. The density therefore increases while the total organic carbon content decreases. At $71 \mathrm{~cm}$ depth, the occurrence of a silty layer causes a strong positive shift of density $\left(\delta=0.37 \mathrm{~g} / \mathrm{cm}^{3}\right)$ and a negative shift of organic carbon content $\left(\mathrm{C}_{\text {org }}\right.$ $=10.1 \%$ ). Below $71 \mathrm{~cm}$, profiles are relatively linear with small fluctuations between pure peat values (i.e. value of the $1 \mathrm{~cm}$ depth sample) and silty values (i.e. value of the $71 \mathrm{~cm}$ depth sample), reflecting the clayey character of the samples. At the lowermost $20 \mathrm{~cm}$, HRSM increases rapidly, indicating a strong lithological change that represents the base of the peat infilling.

\section{Major elements}

Major element analysis reveals that $\mathrm{Al}, \mathrm{Ca}$ and $\mathrm{Fe}$ are the most abundant elements in PB2: average $[\mathrm{Al}]_{\mathrm{PB} 2}=6.5 \mathrm{wt} . \%$, average $[\mathrm{Ca}]_{\mathrm{PB} 2}=3.5 \mathrm{wt} . \%$ and average $[\mathrm{Fe}]_{\mathrm{PB} 2}=3.5$ wt. $\%$ (Table 2). All the major elements display similar variation with depth: decreasing values from $198 \mathrm{~cm}$ depth, then increasing and peaking at $90 \mathrm{~cm}$, finally decreasing again until the surface. Although concentrations are lower, $\mathrm{PB} 4$ displays the same trend in elemental abundance: average $[\mathrm{Al}]_{\mathrm{PB} 4}=3.3 \mathrm{wt} . \%$, average $[\mathrm{Ca}]_{\mathrm{PB} 4}=0.97 \mathrm{wt} . \%$ and average $[\mathrm{Fe}]_{\mathrm{PB} 4}=$ 0.98 wt. \%. P is often below detection limits. As in PB2, all the major elements show remarkably comparable profiles: concentrations peak slightly at 390, 310 and $160 \mathrm{~cm}$ depth, then decrease and peak strongly at $71 \mathrm{~cm}$, to finally sharply decrease until the surface. 
Table 2. Weight percentage of major elements in samples from Galletué (PB2) and San Pablo de Tregua (PB4). $<$ DL: under detection limits (i.e. $<3 \sigma$ ); values in italic: quantitative measurements (i.e. $>9 \sigma$ ); underlined values: semiquantitative measurements (i.e. $3 \sigma-6 \sigma$ ).

\begin{tabular}{|c|c|c|c|c|c|c|c|c|c|}
\hline Depth & & & & & & & & & \\
\hline$(\mathrm{cm})$ & $\mathrm{Ti}$ & Al & $\mathrm{Fe}$ & $\mathrm{Mn}$ & $\mathrm{Mg}$ & $\mathrm{Ca}$ & $\mathrm{Na}$ & $\mathrm{K}$ & $\mathrm{P}$ \\
\hline \multicolumn{10}{|l|}{ Galltetué (PB2) } \\
\hline 3.5 & 0.35 & 4.8 & 4.4 & 0.06 & 1.5 & 3.6 & 1.2 & 0.27 & 0.07 \\
\hline 29 & 0.20 & 2.6 & 1.6 & 0.02 & 0.44 & 1.7 & 0.64 & 0.15 & 0.05 \\
\hline 70 & 0.35 & 4.25 & 2.3 & 0.04 & 0.60 & 2.3 & 1.0 & 0.23 & $<\mathrm{DL}$ \\
\hline 90 & 0.63 & 9.9 & 4.8 & 0.09 & 1.4 & 6.4 & 2.4 & 0.43 & 0.07 \\
\hline 108 & 0.55 & 6.6 & 4.0 & 0.07 & 1.1 & 3.8 & 1.9 & 0.44 & 0.10 \\
\hline Replicate 108 & 0.55 & 6.7 & 3.9 & 0.07 & 1.2 & 4.1 & 2.0 & 0.48 & $<\mathrm{DL}$ \\
\hline 128 & 0.58 & 6.3 & 3.2 & 0.06 & 0.80 & 3.3 & 1.8 & 0.41 & 0.12 \\
\hline 152 & 0.62 & 6.6 & 3.6 & 0.08 & 0.84 & 3.4 & 2.3 & 0.47 & 0.09 \\
\hline 177 & 0.61 & 7.7 & 3.3 & 0.06 & 0.94 & 3.5 & 2.1 & 0.42 & $<\mathrm{DL}$ \\
\hline 198 & 0.66 & 8.4 & 4.2 & 0.09 & 1.1 & 4.1 & 2.7 & 0.62 & 0.10 \\
\hline 227 & 0.61 & 7.5 & 3.5 & 0.07 & 0.84 & 3.5 & 2.3 & 0.48 & 0.12 \\
\hline \multicolumn{10}{|l|}{$\begin{array}{c}\text { San Pablo de Tregua } \\
\text { (PB4) }\end{array}$} \\
\hline 1 & 0.01 & 0.17 & 0.09 & 0.06 & 0.30 & 1.2 & $\underline{0.17}$ & 0.24 & $<\mathrm{DL}$ \\
\hline 3 & 0.01 & 0.15 & 0.08 & 0.05 & 0.31 & 1.2 & 0.15 & 0.26 & $<\mathrm{DL}$ \\
\hline 16 & 0.12 & 1.7 & 1.6 & 0.03 & 0.26 & 1.3 & 0.48 & 0.19 & $<\mathrm{DL}$ \\
\hline 47 & 0.48 & 5.5 & 2.1 & 0.04 & 0.51 & 1.5 & 1.7 & 0.76 & 0.15 \\
\hline 71 & 0.89 & 7.4 & 2.4 & 0.05 & 0.70 & 2.1 & 1.8 & 0.73 & $<\mathrm{DL}$ \\
\hline 105 & 0.32 & 4.2 & 0.71 & 0.01 & 0.16 & 0.68 & $\underline{0.35}$ & 0.09 & $<\mathrm{DL}$ \\
\hline 160 & 0.39 & 5.0 & 0.92 & 0.02 & 0.27 & 0.98 & 1.0 & 0.32 & 0.19 \\
\hline 210 & 0.09 & 2.6 & 0.51 & 0.01 & 0.07 & 0.28 & 0.13 & 0.05 & $<\mathrm{DL}$ \\
\hline 246 & 0.09 & 2.5 & 0.38 & 0.01 & 0.07 & 0.25 & 0.12 & $<\mathrm{DL}$ & $<\mathrm{DL}$ \\
\hline 270 & 0.13 & 2.0 & 0.41 & 0.01 & 0.06 & 0.25 & 0.08 & $<\mathrm{DL}$ & $<\mathrm{DL}$ \\
\hline 310 & 0.11 & 1.9 & 0.57 & 0.01 & 0.12 & 0.41 & 0.18 & 0.09 & $<\mathrm{DL}$ \\
\hline Replicate 310 & 0.12 & 1.9 & 0.57 & 0.01 & 0.11 & 0.43 & $\underline{0.16}$ & $<\mathrm{DL}$ & $<\mathrm{DL}$ \\
\hline 340 & 0.39 & 5.6 & 1.9 & 0.02 & 0.63 & 1.3 & 0.59 & 0.12 & $<\mathrm{DL}$ \\
\hline 360 & 0.19 & 4.8 & 1.1 & 0.02 & 0.34 & 1.1 & 0.89 & 0.22 & $<\mathrm{DL}$ \\
\hline Alpehué Pumice & 0.28 & 7.9 & 2.5 & 0.06 & 0.47 & 1.7 & 2.9 & 1.6 & 0.05 \\
\hline Trumaos & 0.79 & 6.0 & 4.2 & 0.16 & 1.8 & 3.7 & 0.89 & 0.20 & 0.07 \\
\hline $\begin{array}{c}\text { Replicate PB2 \%- } \\
\text { deviation }\end{array}$ & 1 & 2.3 & 0.3 & 0.4 & 6.2 & 6.6 & 5.3 & 9.5 & - \\
\hline $\begin{array}{c}\text { Replicate PB4 \%- } \\
\text { deviation }\end{array}$ & 1 & 0.0 & 0.0 & 0.0 & 8.3 & 4.8 & 11.1 & - & - \\
\hline
\end{tabular}

\section{Trace elements}

In PB2 (Table 3) Light Rare Earth elements (LREE) show a weak variation range relative to Heavy Rare Earth elements (HREE). Chondrite-normalized ${ }^{38}$ $\mathrm{La} / \mathrm{Lu}$ ratio $\left(\mathrm{La}_{\mathrm{ch}} / \mathrm{Lu}_{\mathrm{ch}}\right)$ ranging between 2.78 and 2.84. The range of variation is more important in PB4 $\left(\mathrm{La}_{\mathrm{ch}} / \mathrm{Lu}_{\mathrm{ch}}=0.95-9.58\right)$. However, $\mathrm{La}_{\mathrm{ch}} / \mathrm{Lu}_{\mathrm{ch}}$ averages suggest an enrichment in LREE relative to HREE in the two peat soils. Other trace elements show comparable trends as those of REE, reflecting a strong influence of a Trumaos-SVZ particle source. However, $\mathrm{Pb}$ values of PB2 and PB4 show a strong negative anomaly. Based on the behavior of Pb, several potential particle sources to the peat soils could therefore be involved : Trumaos, SVZ and/or Upper Continental Crust. These potential sources will be detailed later (see section 4).

\section{Lead isotopes}

$\mathrm{Pb}$ Isotopic compositions in PB2 and PB4 cores are shown in Table 4 The $\mathrm{Pb}$ isotopic ratios for Galletué (PB2) define relatively constant profiles and small variations: from 18.556 to 18.601 for ${ }^{206} \mathrm{~Pb} /{ }^{204} \mathrm{~Pb}$, from 15.602 to 15.607 for ${ }^{207} \mathrm{~Pb} /{ }^{204} \mathrm{~Pb}$ and from 38.462 to 38.500 for ${ }^{208} \mathrm{~Pb} /{ }^{204} \mathrm{~Pb}$. Except for the three uppermost samples, the $\mathrm{Pb}$ isotopic compositions of San Pablo de Tregua (PB4) also vary in narrow ranges: between 18.371 and 18.655 for ${ }^{206} \mathrm{~Pb} /{ }^{204} \mathrm{~Pb}$, between 15.579 and 15.669 for ${ }^{207} \mathrm{~Pb} /{ }^{204} \mathrm{~Pb}$, and between 38.238 and 38.617 for ${ }^{208} \mathrm{~Pb} /{ }^{204} \mathrm{~Pb}$. Isotopic ratios of the three surface samples shift strongly towards lower values $\left(0.868<{ }^{207} \mathrm{~Pb} /{ }^{206} \mathrm{~Pb}<0.875\right.$ and $\left.2.108<{ }^{208} \mathrm{~Pb} /{ }^{206} \mathrm{~Pb}<2.118\right)$. 
Table 3. Elemental content (ppm) of trace elements in samples from Galletué (PB2). <DL: under detection limits; values in italic: quantitative measurements; underlined values: semi-quantitative measurements.

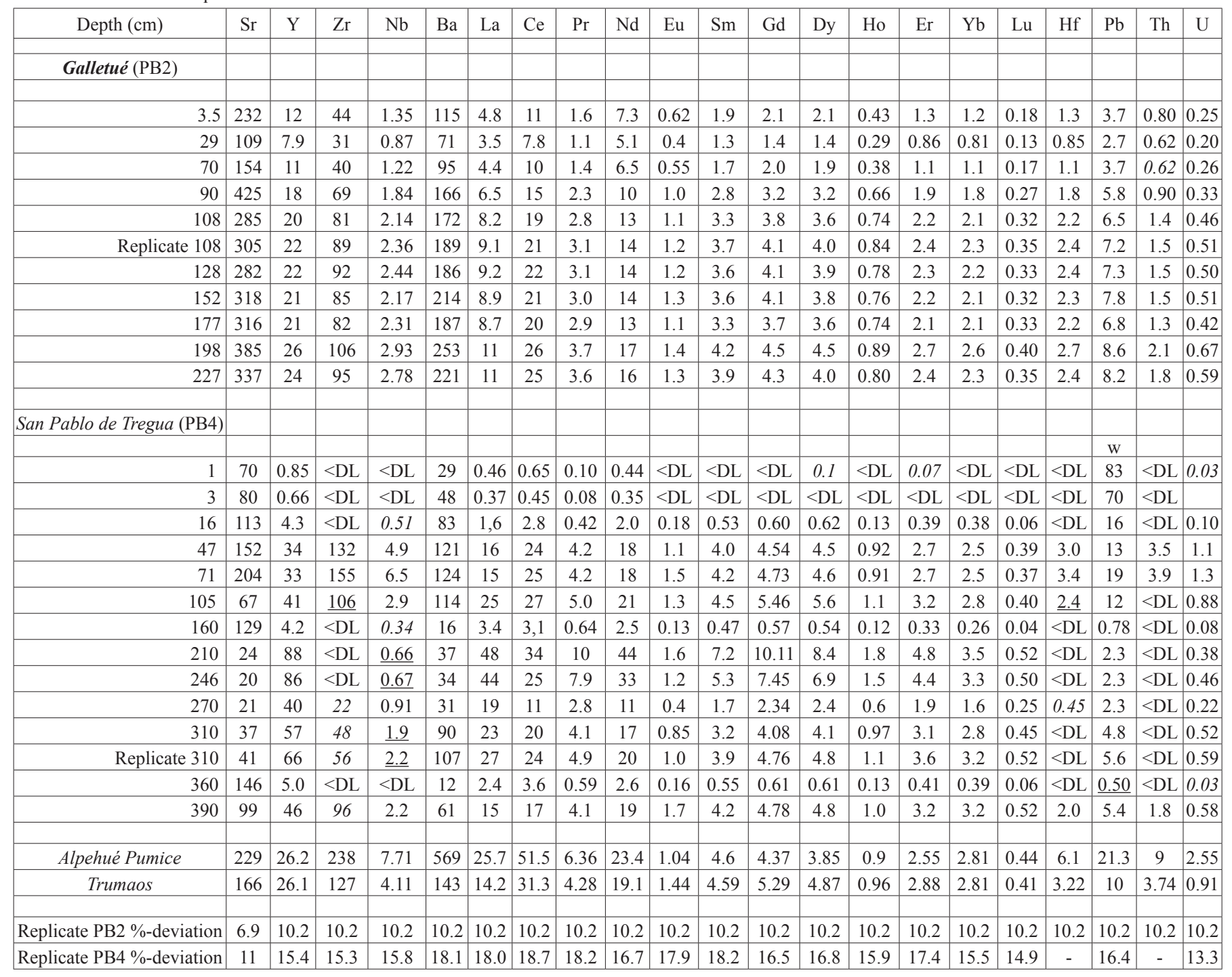

\begin{tabular}{|c|c|c|c|c|c|c|c|c|c|c|}
\hline Depth & ${ }^{206} \mathrm{~Pb} /{ }^{204} \mathrm{~Pb}$ & $2 \sigma$ & ${ }^{207} \mathrm{~Pb} /{ }^{204} \mathrm{~Pb}$ & $2 \sigma$ & ${ }^{208} \mathrm{~Pb} /{ }^{204} \mathrm{~Pb}$ & $2 \sigma$ & ${ }^{208} \mathrm{~Pb} /{ }^{206} \mathrm{~Pb}$ & $2 \sigma$ & ${ }^{207} \mathrm{~Pb} /{ }^{206} \mathrm{~Pb}$ & ${ }^{2 \sigma}$ \\
\hline (cm) & & & & & & & & \\
\hline Galletué (PB2) & & & & & & & & & & \\
\hline \hline 3.5 & 18.5564 & 14 & 15.6053 & 12 & 38.4622 & 31 & 2.0727 & 5 & 0.8409 & 2 \\
\hline 29 & 18.5820 & 17 & 15.6072 & 16 & 38.4916 & 40 & 2.0714 & 3 & 0.8399 & 1 \\
\hline 70 & 18.5727 & 13 & 15.6020 & 11 & 38.4761 & 30 & 2.0716 & 4 & 0.8400 & 1 \\
\hline 90 & 18.5722 & 16 & 15.6037 & 13 & 38.4771 & 32 & 2.0718 & 5 & 0.8402 & 2 \\
\hline 108 & 18.5710 & 9 & 15.6039 & 7 & 38.4737 & 17 & 2.0717 & 3 & 0.8402 & 1 \\
\hline 128 & 18.5956 & 10 & 15.6064 & 12 & 38.4974 & 30 & 2.0703 & 4 & 0.8393 & 1 \\
\hline 152 & 18.5927 & 10 & 15.6045 & 9 & 38.4950 & 25 & 2.0705 & 4 & 0.8393 & 1 \\
\hline 177 & 18.6014 & 14 & 15.6070 & 11 & 38.5002 & 28 & 2.0699 & 4 & 0.8391 & 1 \\
\hline Replicate 177 & 18.8800 & 9 & 15.6026 & 9 & 38.4756 & 27 & 2.0699 & 5 & 0.8394 & 1 \\
\hline 198 & 18.5855 & 10 & 15.6057 & 9 & 38.4881 & 26 & 2.0709 & 5 & 0.8397 & 1 \\
\hline 227 & 18.5820 & 12 & 15.6032 & 13 & 38.4850 & 32 & 2.0711 & 4 & 0.8397 & 1 \\
\hline
\end{tabular}

San Pablo de Tregua (PB4) 
Table 4. Analyses of lead isotopes in samples from Galletué (PB2) and San Pablo de Tregua (PB4). Italic value (when $2 \sigma<100 \times 10^{-4}$ ) have to be considered as qualitative data.

\begin{tabular}{|c|c|c|c|c|c|c|c|c|c|c|}
\hline 1 & 17.7952 & 7 & 15.5737 & 6 & 37.6848 & 19 & 2.1176 & 5 & 0.8751 & 1 \\
\hline 3 & 17.7799 & 8 & 15.5710 & 8 & 37.6660 & 23 & 2.1184 & 6 & 0.8758 & 2 \\
\hline 16 & 17.9551 & 64 & 15.5879 & 54 & 37.8373 & 139 & 2.1077 & 80 & 0.8682 & 4 \\
\hline 47 & 18.5892 & 169 & 15.6408 & 146 & 38.5411 & 356 & 2.0732 & 13 & 0.8413 & 7 \\
\hline 71 & 18.5136 & 47 & 15.6088 & 42 & 38.4114 & 101 & 2.0745 & 8 & 0.8429 & 4 \\
\hline 105 & 18.5856 & 64 & 15.6246 & 55 & 38.5147 & 131 & 2.0719 & 9 & 0.8406 & 4 \\
\hline 160 & 18.5469 & 148 & 15.5888 & 122 & 38.4206 & 304 & 2.0715 & 19 & 0.8405 & 7 \\
\hline 210 & 18.5435 & 100 & 15.6338 & 83 & 38.4684 & 200 & 2.0747 & 14 & 0.8431 & 6 \\
\hline 246 & 18.6546 & 17 & 15.6689 & 15 & 38.6174 & 37 & 2.0701 & 5 & 0.8399 & 24 \\
\hline 270 & 18.4576 & 116 & 15.6145 & 100 & 38.3621 & 250 & 2.0785 & 18 & 0.8459 & 9 \\
\hline 310 & 18.5601 & 153 & 15.5792 & 131 & 38.4197 & 324 & 2.0701 & 20 & 0.8394 & 10 \\
\hline 340 & 18.5605 & 46 & 15.6028 & 41 & 38.4549 & 102 & 2.0715 & 9 & 0.8407 & 3 \\
\hline 360 & 18.3714 & 20 & 15.5913 & 20 & 38.2376 & 53 & 2.0814 & 4 & 0.8486 & 3 \\
\hline Trumaos & 18.6049 & 7 & 15.9079 & 7 & 38.5087 & 220 & 2.0698 & 1 & 0.8390 & 8 \\
\hline Alpehué pumice & 18.5454 & 9 & 15.6021 & 8 & 38.4541 & 25 & 2.0735 & 6 & 0.8413 & 8 \\
\hline
\end{tabular}

\section{DISCUSSION}

Natural vs. anthropogenic sources

Trace element concentrations normalized to chondrite values ${ }^{38}$ are reported as spider diagrams (Fig. 3). Profiles of average concentrations for the two peat soils are compared to average compositions of the Trumaos, the Chilean Southern Volcanic Zone (SVZ) soils and the average Upper Continental Crust (UCC). Trends suggest a dominant particle sources comparable to the SVZ products and Trumaos. Galletué area (PB2) is closer to the SVZ profile than PB4. It is consistent with the influence made by the numerous tephra layers found in the core. This is also consistent with the lithology: PB2 is rather a peaty sediment rich in volcanic particles, than a pure (i.e. organic) peat. San Pablo de Tregua (PB4) core as a whole has a comparable lithology to PB2 although it displays less abundant volcanic layers.

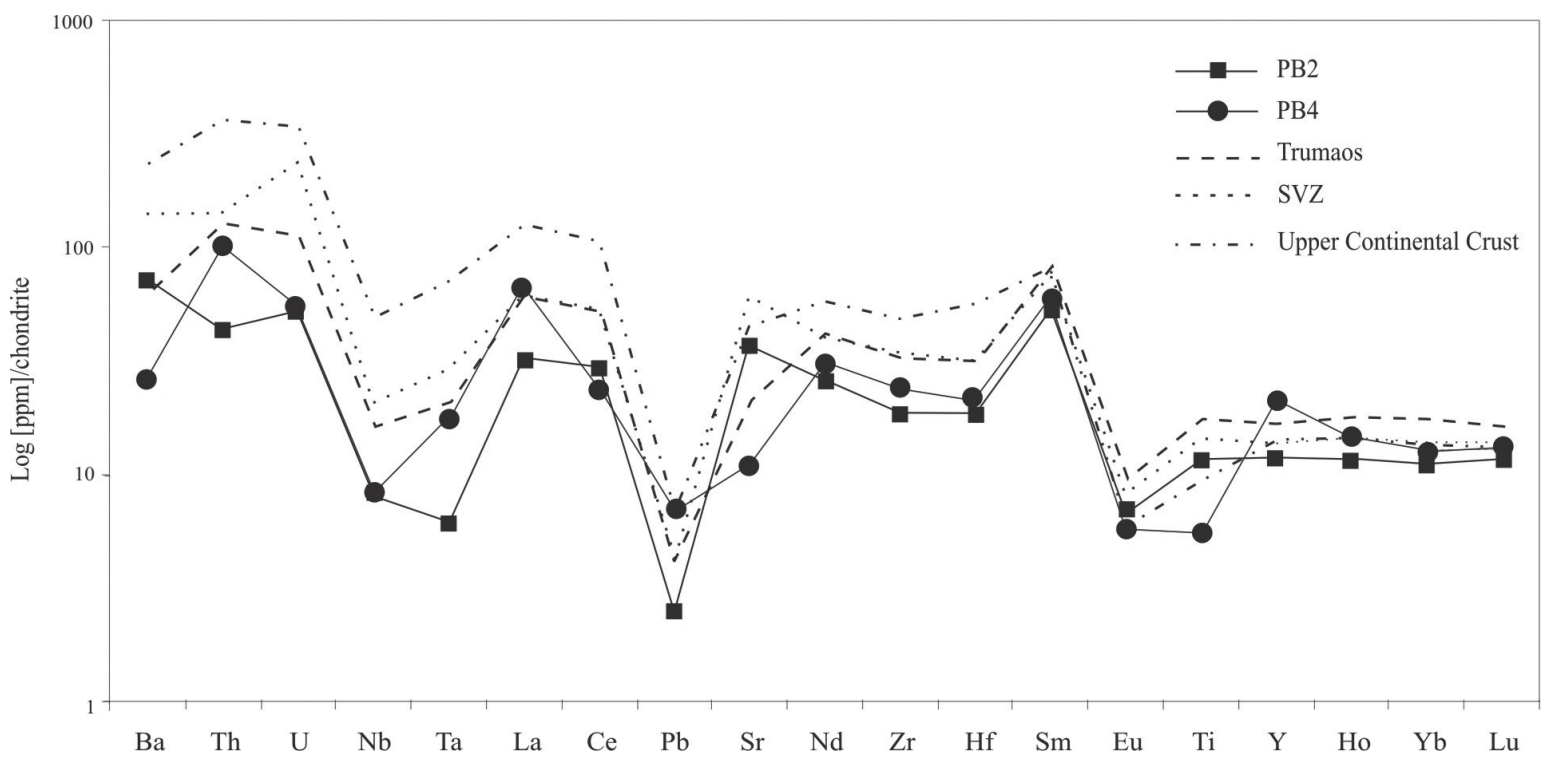

Figure 3. Spider diagrams $\mathrm{s}^{39}$ normlized to chondrites ${ }^{38}$ for the two sites and Trumaos compared with $\mathrm{SVZ}^{40-57}$ and Upper continental crust ${ }^{58}$.

$\mathrm{Pb}$ isotopic data for Galletue (PB2) show a narrow range of variation and are included within the Trumaos-SVZ isotopic data field (Fig. 4.A.). A significant shift in ${ }^{206} \mathrm{~Pb} /{ }^{207} \mathrm{~Pb}$ is recorded between the two samples taken below $(127.75 \mathrm{~cm})$ and above $(108.25 \mathrm{~cm})$ the Alpehue Pumice, a well known rhyodacitic volcanic layer erupted from Caldera Sollipulli at $3000 \mathrm{yr}$ cal $\mathrm{BP}^{59}$. The measured isotopic ratios are shifted from the Trumaos trend to the Alpehué Pumice isotopic composition (Fig. 4. B and C). This is due to contamination by grains from Alpehué Pumice dispersed in nearby upper layers, providing a pumiceous contribution to the isotopic signature of the peaty sediment. The shift shown by the sub-surface sample ( $3 \mathrm{~cm}$ depth) is too small $\left(\mathrm{e} . \mathrm{g}\right.$. $\left.{ }^{206} \mathrm{~Pb} /{ }^{204} \mathrm{~Pb}=18.564 \pm 0.0014\right)$ regarding to $\mathrm{Pb}$ isotopic ratios in actual Chilean cities aerosols ${ }^{60}\left({ }^{206} \mathrm{~Pb} / 204 \mathrm{~Pb}=17.00 \pm 0.02\right)$ to invoke any anthropogenic contribution to the $\mathrm{Pb}$ isotopic composition for the 
subsurface sample of Galletué core. The shallowest sample has probably been taken under the anthropogenically contaminated layers. Note that it was not possible to sample the subsurface layers due to contamination by sparse tephra grains. Moreover, in cores from Lake Galletué, no anthropogenic influence is recorded in terms of fossil fuel pollution ${ }^{61}$. Anthropogenic particles originating from a long distance source are negligible ${ }^{61}$.

\section{Galletue (PB2)}

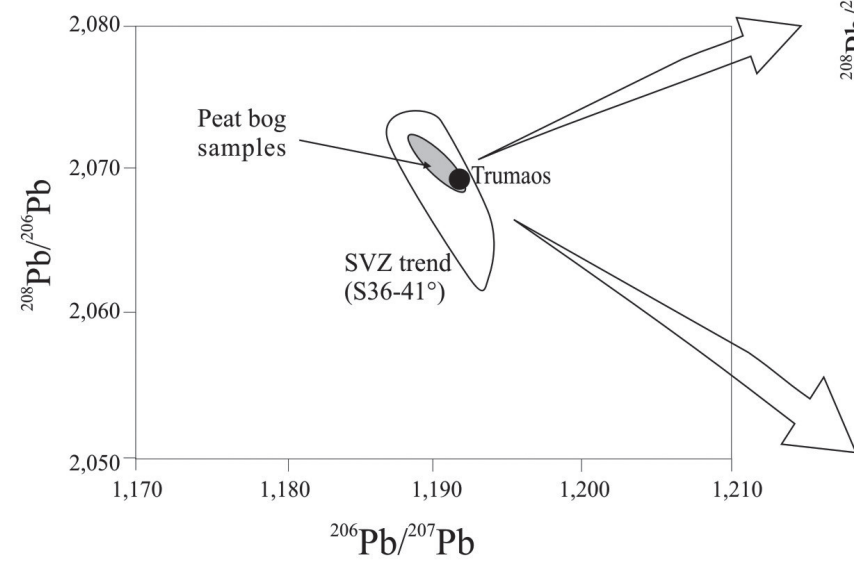

A
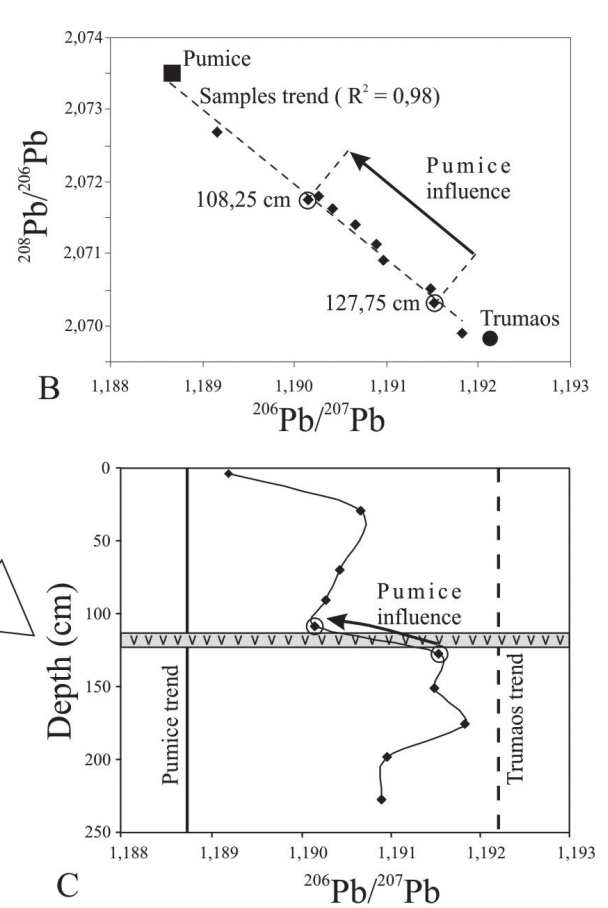

\section{San Pablo de Tregua (PB4)}
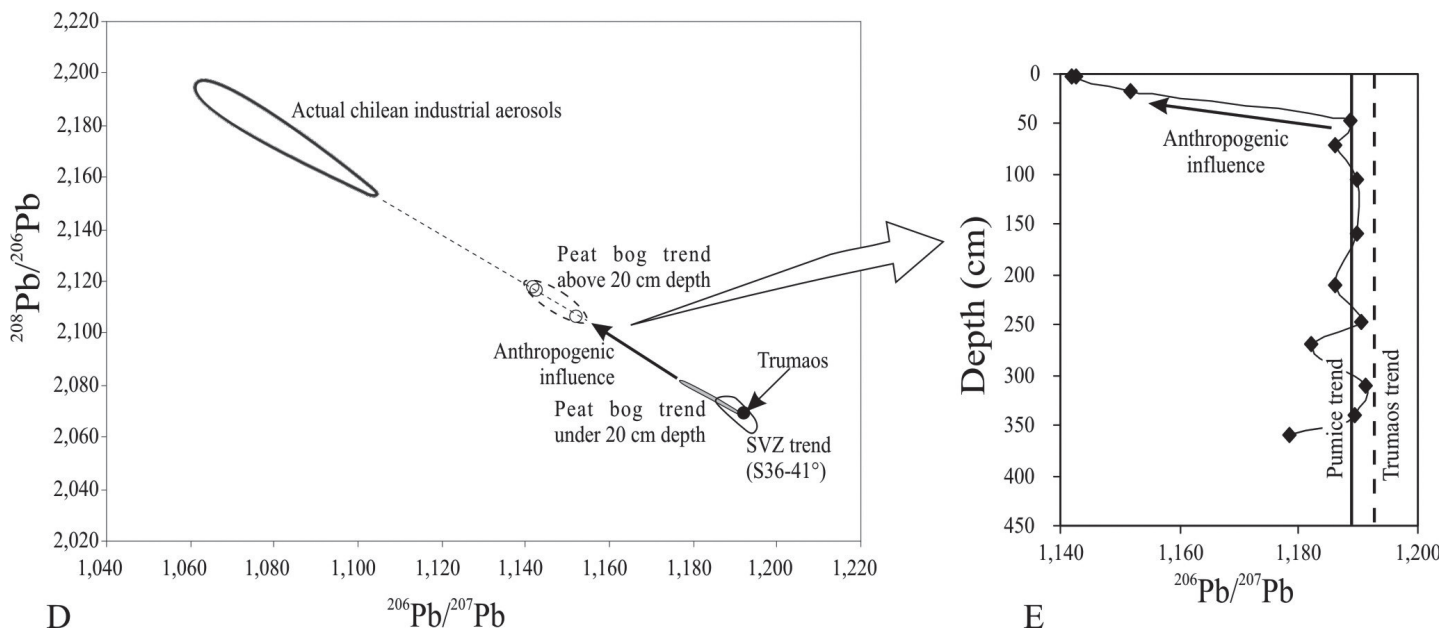

Figure 4. ${ }^{206} \mathrm{~Pb} / 207 \mathrm{~Pb}$ vs. ${ }^{208} \mathrm{~Pb} /{ }^{206} \mathrm{~Pb}$ isotopic biplot of PB2 (A.) and PB4 (D.) SVZ: field of SVZ ratios (95\% confidence) ${ }^{41,42,46-48,50-52,55,56,62,63}$. SVZ*: possible extension to higher ${ }^{207} \mathrm{~Pb} / 206 \mathrm{~Pb}$ values ${ }^{43,49,65}$. Average Upper Continental Crust from litterature ${ }^{58}$. Actual Chilean industrial aerosols (younger than 1994) from the cities of Concepción, Villarrica and Punta Arenas ${ }^{59}$. B. and C. Influence of the pumice layer on the isotopic biplot and the ${ }^{206} \mathrm{~Pb} /{ }^{207} \mathrm{~Pb} v s$. depth profile, respectively. E. Depth evolution of ${ }^{206} \mathrm{~Pb} / 207 \mathrm{~Pb}$ in San Pablo de Tregua (PB4).

Variation in $\mathrm{Pb}$ isotopic ratios ranges are ten times wider for San Pablo de Tregua (PB4) relative to PB2. Sediments sampled above $20 \mathrm{~cm}$ depth display isotopic ratios $\left({ }^{206} \mathrm{~Pb} /{ }^{207} \mathrm{~Pb}<1.16,{ }^{208} \mathrm{~Pb} /{ }^{206} \mathrm{~Pb}>2.10\right)$ strongly shifted towards anthropogenic field (Fig. 4. D. and E) here reported by Actual Chilean industrial aerosols ${ }^{59}$. As it was already suggested by the high Pb E.F., Pb isotopic signatures of the three uppermost samples $(1,3$, and $20 \mathrm{~cm})$ reflect conjugated inputs of both SVZ volcanic particles and actual industrial aerosols. ${ }^{206} \mathrm{~Pb} /{ }^{207} \mathrm{~Pb}$ ratios were reported to vary between 1.12 and 1.14 associated Pb E.F. higher than 60 in Antarctic ice core samples ${ }^{19,20}$ aging from 1950 A.D. to 1987 A.D. Moreover, ice samples dating from the early 1900's A.D. to about 1940 A.D. show preferentially ${ }^{206} \mathrm{~Pb} /{ }^{207} \mathrm{~Pb}$ varying between 1.15 and 1.18, and lower $\mathrm{Pb}$ E.F. Therefore, despite a lack of dating for our samples, we could assume a young age (1940 A.D.-2000 
A.D.) for the two uppermost samples of PB4 on the basis of their low ${ }^{206} \mathrm{~Pb} / 207 \mathrm{~Pb}$ ratios $(1.12-1.14)$, strong $\mathrm{Pb}$ enrichment and extremely high $\mathrm{Pb}$ E.F. With a ${ }^{206} \mathrm{~Pb} /{ }^{207} \mathrm{~Pb}$ ratio of 1.15 and lower $\mathrm{Pb}$ E.F. (13), the third sample (16 cm depth) could be rather older. However, further sampling and dating of PB4 core would have been necessary to specify the exact age of this anthropogenic influence, but tephra grains contaminating surface samples peat make this sampling very tricky.

Changes in particle fluxes and Crustal involvment

$\mathrm{PB} 2$ samples show a $\mathrm{Al} / \mathrm{Ti}$ profile with an opposite trend relative to $\mathrm{Nd} / \mathrm{Ti}$ and $\mathrm{Pb} / \mathrm{Ti}$ profiles (Fig. 5). All the normalized profiles are included within the range of Trumaos and SVZ values, except for Al/Ti. This latter profile ranges between (1) the Trumaos and/or the SVZ and (2) the average Upper Continental Crust $\mathrm{Al} / \mathrm{Ti}$ values, suggesting a possible crustal contamination. Pb E.F. profile (calculated with Trumaos reference) suggests a unique mineral source for PB2. Nd/Ti and $\mathrm{Pb} / \mathrm{Ti}$ profiles suggest a mineral particle source with a volcanic geochemical signature reflecting the Trumaos and/or SVZ compositions, as already shown by spider diagrams. Trumaos are easily eroded and carried by wind. It is therefore assumed that the SVZ signature is due to the Trumaos inputs rather than particles issued from solid volcanic rocks weathering or direct volcanic supply.
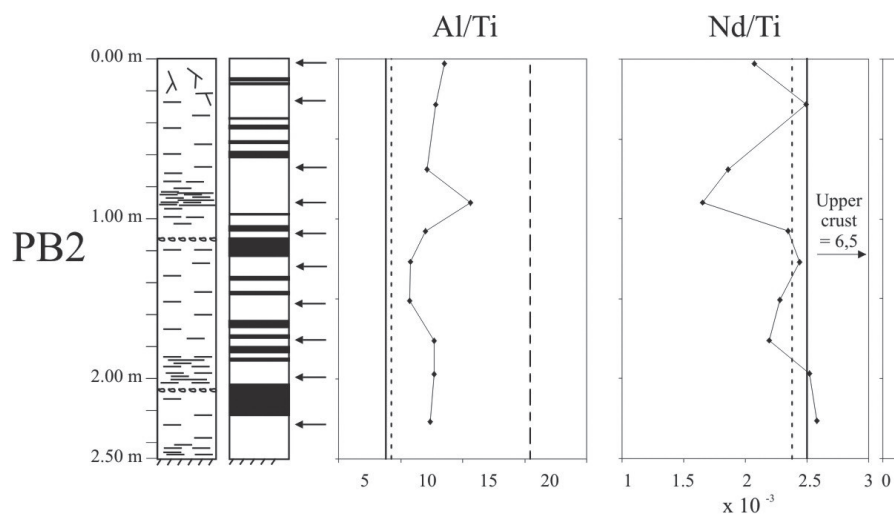

$\mathrm{Pb} / \mathrm{Ti}$

$\mathrm{Pb}$ E.F.
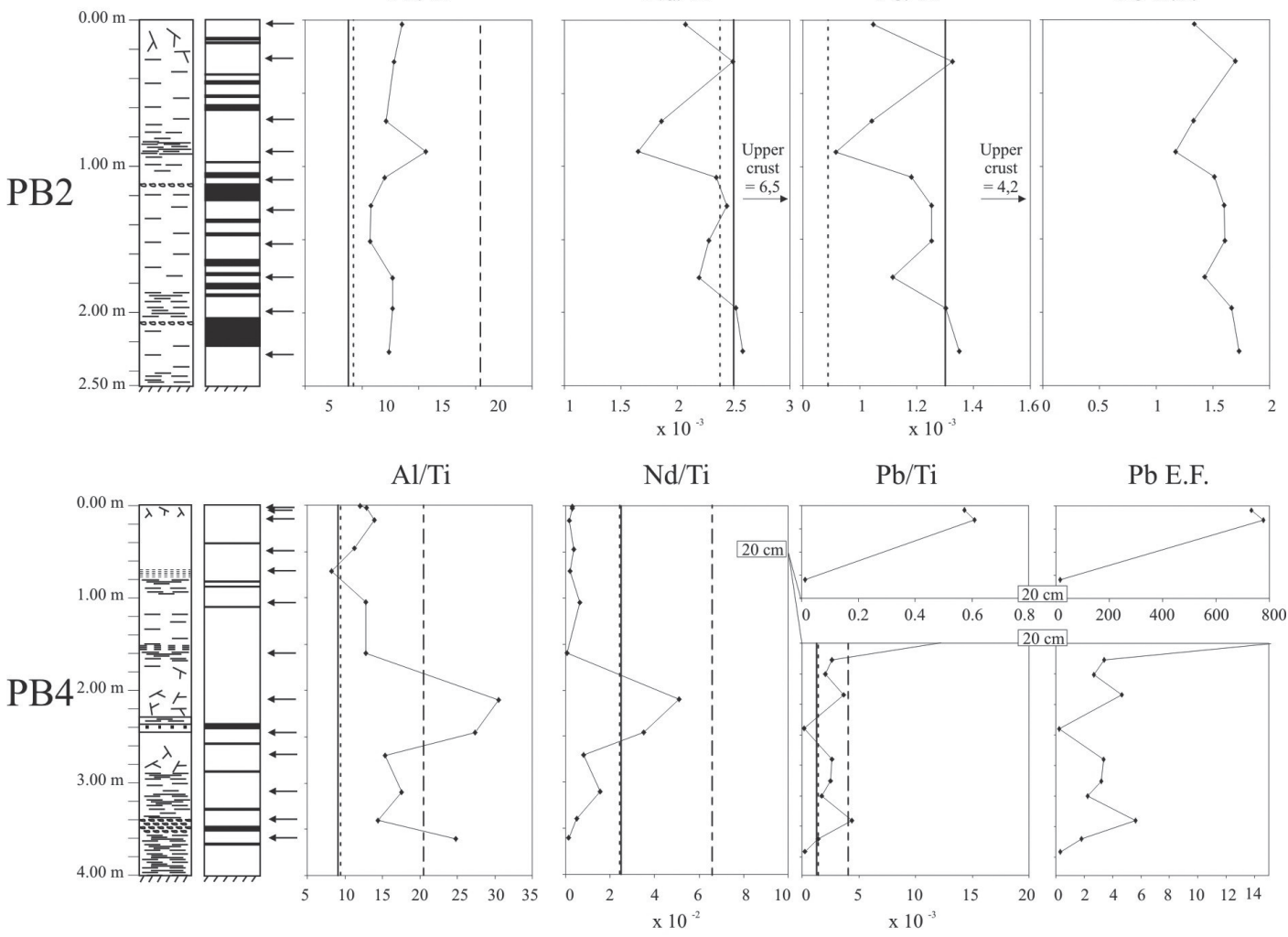

$\mathrm{Pb} / \mathrm{Ti}$

$\mathrm{Pb}$ E.F.

Trumaos

SVZ

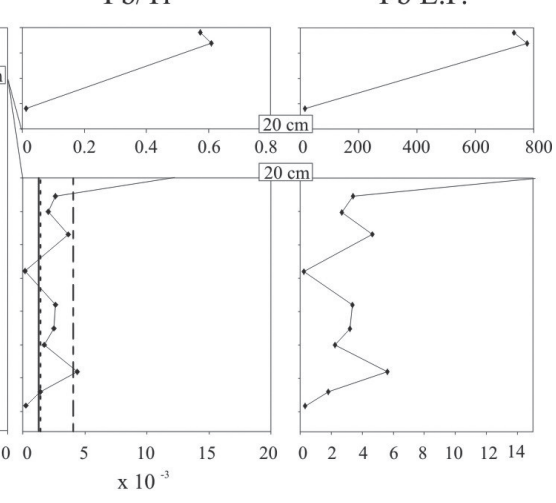

---- Upper Continental Crust

Figure 5. Ratio profiles ( $\mathrm{Al} / \mathrm{Ti}, \mathrm{Nd} / \mathrm{Ti}, \mathrm{Pb} / \mathrm{Ti}$ ) and $\mathrm{Pb}$ enrichment factor (calculated using Trumaos values) of the two profiles. SVZ: mean value (for references, see figure 4). Upper continental crust: values from litterature ${ }^{58}$.

In PB4, Ti-normalized profiles of $\mathrm{Al}$ and $\mathrm{Nd}$ are roughly comparable. As a whole, the profiles are included within the composition ranges of SVZ and Trumaos. However, three peaks show significantly high ratios exceeding the $\mathrm{SVZ}$ and Trumaos composition ranges. They correspond to high Al/Ti values between at about $360 \mathrm{~cm}$ depth and high $\mathrm{Al} / \mathrm{Ti}$ and $\mathrm{Nd} / \mathrm{Ti}$ values between 210 and $246 \mathrm{~cm}$ depth (Fig. 5). These compositional shifts suggest a possible crustal particles input. Moreover, $\mathrm{Pb} / \mathrm{Ti}$ and $\mathrm{Pb}$ E.F. profiles show also higher values trending towards crustal composition between 210 and $246 \mathrm{~cm}$ depth but not at $360 \mathrm{~cm}$ depth. Pb E.F. also shows higher values (approximately 3 and 5.5 , respectively) between $210 \mathrm{~cm}$ and $246 \mathrm{~cm}$ but again not at $360 \mathrm{~cm}$ depth. These observations suggest involvement of a crustal particle source. The strong peak clearly observed at $71 \mathrm{~cm}$ depth in the Ti, Ti flux, and $\mathrm{Pb}$ E.F. profiles, is missing in Ti-normalized profiles. This contrast suggests that the $71 \mathrm{~cm}$ depth silty layer is mainly composed of volcanic derived material (Trumaos). $\mathrm{Pb} / \mathrm{Ti}$ and $\mathrm{Pb}$ E.F. profiles display natural background (i.e. Trumaos) in the lower part of the core, while the uppermost $20 \mathrm{~cm}$ of sediments are strongly enriched in $\mathrm{Pb}$.
Figure 6 presents Ti concentrations, Ti fluxes and particulate fluxes for the two peat soils. Galletué (PB2) samples show extremely high fluxes in Ti and particles, averaging $0.93 \mathrm{~g} / \mathrm{m}^{2} / \mathrm{yr}$ and $158 \mathrm{~g} / \mathrm{m}^{2} / \mathrm{yr}$, respectively. For comparison, in Swiss peat bogs ${ }^{10}$, the Younger Dryas is recorded by a strong dust peak averaging $11.5 \mathrm{~g} / \mathrm{m}^{2} / \mathrm{yr}$ while the natural background dust flux is less than 0.5 $\mathrm{g} / \mathrm{m}^{2} / \mathrm{yr}$. At $90 \mathrm{~cm}$ depth, a shift in [Ti] is correlated with a strong peak in $\mathrm{Ti}$ flux and particulate flux. Between 130 and $180 \mathrm{~cm}$, a slight increase in [Ti] is also recorded in the three profiles. However, ${ }^{1{ }^{47}} \mathrm{Sm} /{ }^{144} \mathrm{Nd}$ signatures calculated from $\mathrm{Sm}$ and $\mathrm{Nd}$ concentrations (for more details, see figure 7 caption) of the Galletúe (PB2) samples confirm that the dominant source of atmospheric particles to the peat soils is related to the SVZ-Trumaos component (Fig. 6). The possible contribution of a crustal sources for the $90 \mathrm{~cm}$ depth sample, previously suggested by the $\mathrm{Al} / \mathrm{Ti}$ ratio, is inconsistent with the ${ }^{147} \mathrm{Sm} /{ }^{144} \mathrm{Nd}$ results. The high values recorded by the PB2 sample reflect abundant inputs of Trumaos and other volcanic weathering particles inputs. 


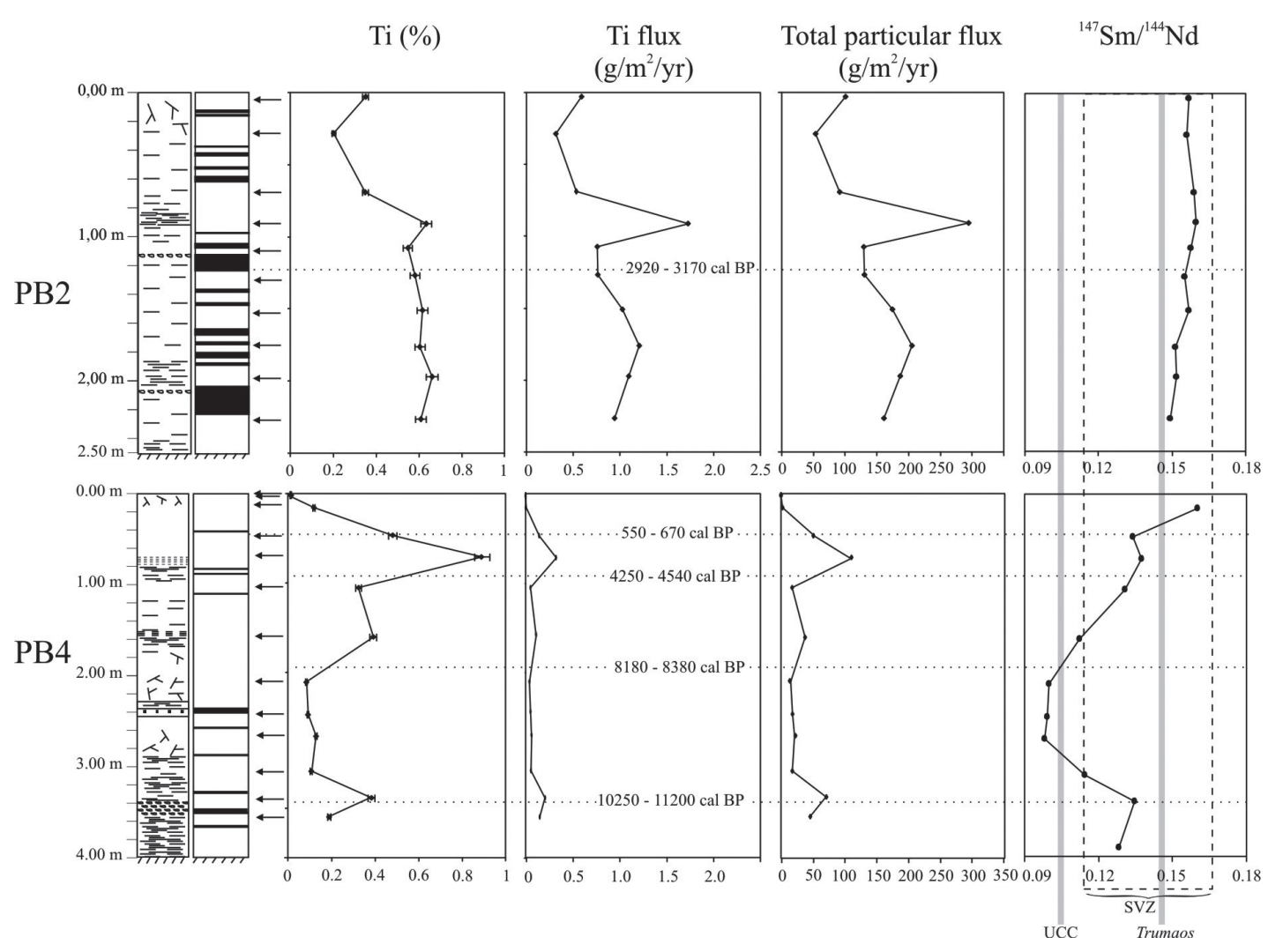

Figure 6. Ti concentration, Ti flux, total particle flux and ${ }^{147} \mathrm{Sm} /{ }^{144} \mathrm{Nd}$ profiles. Arrows indicate samples depth. SVZ: mean value from litterature ${ }^{40-57}$, so as Upper continental crust values ${ }^{58}$. ${ }^{147} \mathrm{Sm} /{ }^{144} \mathrm{Nd}$ is calculated using $[\mathrm{Sm}] /[\mathrm{Nd}]$ in sample multiplied by the ratio between natural abundance of ${ }^{147} \mathrm{Sm}$ in $\mathrm{Sm}$ and natural abundance of ${ }^{144} \mathrm{Nd}$ in $\mathrm{Nd}($ i.e. 0.60847$) .{ }^{147} \mathrm{Sm} /{ }^{144} \mathrm{Nd}$ results for $1 \mathrm{~cm}$ and $3 \mathrm{~cm}$ depth samples in PB4 are not represented, because Sm and Nd concentration measurements are under detection limits.

In San Pablo de Tregua (PB4), flux values are globally lower relative to PB2. [Ti] flux and total particular flux average $0.18 \mathrm{~g} / \mathrm{m}^{2} / \mathrm{yr}$ and $31 \mathrm{~g} / \mathrm{m}^{2} / \mathrm{yr}$, respectively. In the three profiles of PB4, a peak is located at $71 \mathrm{~cm}$ depth (Fig. 6). ${ }^{147} \mathrm{Sm} /{ }^{144} \mathrm{Nd}$ data mainly plot in the SVZ isotopic field (Fig. 6) except for five samples $(130 \mathrm{~cm}, 210 \mathrm{~cm}, 246 \mathrm{~cm}, 270 \mathrm{~cm}$ and $310 \mathrm{~cm})$. Samples 160 $\mathrm{cm}$ and $310 \mathrm{~cm}$ depth may reflect contamination by a crustal input as they are at the limit of the SVZ and Upper Continental Crust isotopic fields (Fig. 6). In addition they display opposite trends in $\mathrm{Pb} / \mathrm{Ti}$ and $\mathrm{Pb}$ E.F. profiles. However, sample at $160 \mathrm{~cm}$ depth shows negative shifts $\left(\mathrm{Pb} / \mathrm{Ti}=2 \times 10^{-3}, \mathrm{~Pb}\right.$ E.F. $\left.=1.6\right)$ while sample at $310 \mathrm{~cm}$ shows positive ones $\left(\mathrm{Pb} / \mathrm{Ti}=7 \times 10^{-3}\right.$, Pb E.F.= 5.6). Therefore, it is doubtful to interpret them as contaminated by crustal particles. Samples from $210 \mathrm{~cm}, 246 \mathrm{~cm}$ and $270 \mathrm{~cm}$ depth are distinguishable from the others by significant lower ${ }^{147} \mathrm{Sm} /{ }^{144} \mathrm{Nd}$ values, reflecting potential contribution of a crustal source. This is especially consistent for the 210 and $246 \mathrm{~cm}$ samples because they present strong peaks in $\mathrm{Al} / \mathrm{Ti}, \mathrm{Nd} / \mathrm{Ti}, \mathrm{Pb} / \mathrm{Ti}$ and $\mathrm{Pb}$ E.F. Those observations suggest a possible involvement of a long range crustal dust source during corresponding deposition period, strongly influencing ${ }^{147} \mathrm{Sm} /{ }^{144} \mathrm{Nd}$ signatures of these layers.

\section{Summary and conclusions}

We investigated peat cores from Chilean lake district. In this region, continental archives are frequently affected by volcanic falls. The availability of soft ash-derived Andosoils (i.e. Trumaos) material provides a continuous particle rain input in the Lake District. Short-term high fluxes of particles from various origins appeared to reflect punctual events. Cores from Galletué and San Pablo de Tregua peat soils (Chilean Lake District, South Chile) record ca 6000 and 10000 years of atmospheric particle deposition. Those peat soils are characterized by a minerotrophic matrix rich in volcanic dust with variable organic content. The use of major and trace elements data as well as $\mathrm{Pb}$ isotopes allow to decipher between three the particles categories supplied to the peat soils: a) SVZ weathering products (Trumaos) $(0<$ Pb E.F. $<2$ and $\left.1.185<^{206} \mathrm{~Pb} / 207 \mathrm{~Pb}<1.195\right)$ providing a great amount of erodible material easily transported by wind, and constituting the local and main particles source; b) a mix of SVZ weathering products and long range crustal particles $(2<\mathrm{Pb}$ E.F. $<6$ and ${ }^{1{ }^{14}} \mathrm{Sm} /{ }^{144} \mathrm{Nd}<0.105$ to 0.115 ), only recorded in San Pablo de Tregua; c) an anthropogenic undifferentiated source (Pb E.F. $>6$ and ${ }^{207} \mathrm{~Pb} / 206 \mathrm{~Pb}>0.865$ ) only recorded in the uppermost $20 \mathrm{~cm}$ of San Pablo de Tregua (PB4).

In Galletué (PB2) core, a clayey layer induces a peak in several elemental profiles at $90 \mathrm{~cm}$ depth. Particularly, the total particle flux reaches $158 \mathrm{~g} / \mathrm{m}^{2} / \mathrm{yr}$, which is extremely high. This particular clayey level could suggest a climatic change corresponding to a warmer period with a main volcanic atmospheric dust supply. Since this period, no crustal aerosol input is detected.

In San Pablo de Tregua (PB4) core, the particle source below $20 \mathrm{~cm}$ depth is the SVZ-Trumaos source. Above this depth, the signature is a mix between SVZ-Trumaos and the industrial sources, reflecting the inception of the anthropogenic influence. In PB4, two periods of $\mathrm{Pb}$ pollution could be distinguished by comparison with isotopic values from the Antarctic ice cap ${ }^{19,20}$. The sample at $16 \mathrm{~cm}$ could be related to the beginning of the $20^{\text {th }}$ century while the two uppermost ones reflect more likely the isotopic signature of the period between 1950 and 1987. Moreover the isotopic signatures between $210 \mathrm{~cm}$ and $246 \mathrm{~cm}$ suggest punctual crustal involvement, possibly linked to a long range particle transport.

\section{ACKNOWLEDGEMENTS}

We would like to thank O.S.T.C. project EV/12/10B (Coord. M. De Batist, RCMG Gent, Belgium), INQUA and Lefranc Foundation (ULg) for field financial support. Analyses were partially financed by the Belgian National Found for Scientific Research (F.N.R.S.). We thank especially J. De Jong (ULB), J. Navez and L. Monnin (MRAC, Tervuren) for helpful laboratory and analytical assistance, and Sébastien Bertrand and Lourdes Vargas for field assistance. We are also grateful to M. Stürm, E. Chapron (ETH-Zurich) and F. Charlet (RCMG Gent, Belgium) for giving us the possibility to use HR-magnetic susceptibility system. This manuscript has received the kind improvement of 
D. Weis, M. Streel, Maria Gehrels and two anonymous reviewers. During this investigation, François De Vleeschouwer was a F.R.I.A. (F.N.R.S.) fellow.

\section{REFERENCES}

1.- $\quad$ H. Kempter, B. Frenzel, Sci Tot. Environ. 241, 117, (1999).

2.- A. Martínez-Cortizas, X. Pontevedra-Pombal, E. García-Rodeja, J. C. Nóvoa Muñoz, W. Shotyk, Science 284, 939, (1999).

3.- A. Martínez -Cortizas, E. García-Rodeja, X. Pontevedra-Pombal, J. Nóvoa Muñoz, D. Weiss, A. K. Cheburkin Sci Tot. Environ. 292, 33, (2002).

4.- W. Shotyk, D. Weiss, P. G. Appleby, A. K. Cheburkin, R. Frei, M. Gloor, J. D. Kramers, S. Reese, V. D. Knaap, Science 281, 1635, (1998).

5.- W. Shotyk, M. Krachler, A. Martinez-Cortizas, A. K. Cheburkin, H. Emons, Earth planet. Sci. Lett. 199, 21 (2002)

6.- $\quad$ D. Weiss, W. Shotyk, J. D. Kramers, M. Gloor, Atm. Environ. 33, 3751, (1999).

7.- W. Shotyk. Earth Sci. Rev. 25, 95, (1988).

8.- W. Shotyk, Environ. Rev. 4, 149, (1996).

9.- $\quad$ S. West, D.J. Charman, J.P. Grattan, A.K. Cheburkin, Wat. Air. Soil. Poll. 100, 343, (1997).

10.- W. Shotyk, D. Weiss, J. D. Kramers, R. Frei, A. K. Cheburkin, M. Gloor, S. Reese, Geoch. Cosm. Acta 65, 2337, (2001).

11.- W. Shotyk, Sci. Tot. Environ. 292, 19, (2002).

12.- T. M. Mighall, P. W. Abrahams, J. P. Grattan, D. Hayes, S. Timberlake, S. Forsyth, Sci. Tot. Environ. 292, 69, (2002).

13.- S. Baron, M. Lavoie, A. Ploquin, J. Carignan, M. Pulido, J.-L. De Beaulieu, Environ. Sci. Technol. 39, 5131, (2005).

14.- W. Shotyk, A. Sapkota, A.K. Cheburkin, B. Kober, Submitted to Geoch. Cosm. Acta.

15.- A. Sapotka, Mineralogical, chemical, and isotopic ( $\mathrm{Sr}, \mathrm{Pb}$ ) Composition of atmospheric mineral dusts in an ombrotrophic peat bog, Southern South America. PhD Thesis, Ruprecht-Karls-Universität, Heidelberg, Germany, 2006.

16.- H. Biester, A. Martinez-Cortizas, S. Birkenstock, R. Killian, Environ. Sci. \& Technol. 37, 32, (2003).

17.- D. Weiss, W. Shotyk, J. Rieley, S. Page, M. Gloor, S. Reese, A. MartinezCortizas, Geoch. Cosm. Acta 66, 2307, (2002).

18.- I. Basile, F. E. Grousset, M. Revel, J. R. Petit, P. E. Biscaye, N. I. Barkov, Earth planet. Sci. Lett. 146, 573, (1997).

19.- P. Vallelonga, K. van de Velde, J.-P. Candelone, V.I. Morgan, C.F. Boutron, K.J.R. Rosman, Earth planet. Sci. Lett. 204, 291, (2002).

20.- F.A.M. Planchon, K. van de Velde, K.J.R. Rosman, E.W. Wolff, C.P. Ferrari, C.F. Boutron Geoch. Cosm. Acta 67, 693 (2003).

21.- I.E. Belokopytov, V.V. Beresnevich, Torf. Prom. 8, 9, (1955).

22.- P. C. Jowsey, New Phyt. 65, 245, (1965).

23.- B.G. Andersen, G.H. Denton, T.V. Geogr. Ann. 81A, 155, (1999)

24.- G.H. Denton, C.J. Heusser, T.V. Lowell, P.I. Moreno, B.G. Andersen, L.E. Heusser, C. Schlüchter, D.R. Marchant, Geogr. Ann. 81A, 107, (1999a).

25.- G.H. Denton, T.V. Lowell, C.J. Heusser, C. Schlüchter, B.G. Andersen, L.E. Heusser, P.I. Moreno, D.R. Marchant, Geogr. Ann. 81A, 167, (1999b).

26.- R.D. McCullogh, M.J. Bentley, R.S. Purves, N.R.J. Hulton, D.E. Sugden, C.M. Clapperton, J. Quat. Sci. 15, 409, (2000).

27.- O. González-Ferrán Volcanes de Chile. Instituto Geographico militar, Santiago de Chile, 1995.

28.- E. Besoaín in Suelos volcánicos de Chile. J. Tosso ed., Instituto de Investigaciones Agropecuarias (INIA), Santiago de Chile, 1985; pp. 23106.

29.- S. Bertrand, N. Fagel, Catena 73, 10, (2008).

30.- L. V. Vargas-Ramírez, Investigación paleopalinológica en el Sur de Chile $\left(38^{\circ} \mathrm{S}\right.$ a $\left.41^{\circ} \mathrm{S}\right)$. Proceedings the XIV Simposio de Palinología (A.P.L.E.). Salamanca, 2002.
31.- O. Martínez-Miranda, Bosque 4, 3, (1981).

32.- C. Bronk Ramsey, Radiocarbon 43, 355, (2001).

33.- K. Govindaraju, H. de la Roche, Geost. Newsl. 1, 67, (1977).

34.- D. Weis, B. Kieffer, C. Maerschalk, W. Pretorius, J. Barling, Geoch. Geoph., Geos. 6, paper number 10.1029/2004GC000852, (2005).

35.- K. H. Wedepohl, C. W. Correns, D. M. Shaw, K. K. Turekian, J. Zeman Handbook of geochemistry, 13E1-13L2, 21A1-21L1, 22A3-22L2, 40A140L2, 72A1-72L1. Springer-Verlag. Berlin, 1978.

36.- H. W. Nesbitt, G. Markovics, Geoch. Cosm. Acta 61, 1653, (1997).

37.- W. Shotyk, Peat bog archives of atmospheric $\mathrm{Pb}$ deposition. Habilitation Thesis, Geological Institute, University of Berne, 1995.

38.- E Anders, N. Grevesse, Geoch. Cosm. Acta 53, 197, (1989)

39.- S.-S. Sun, W.F. McDonough, in Magmatism in the Ocean Basins. A.D. Saunders, M.L. Norry eds,, Geol. Soc. Spec. Publ. 42, 313 (1989).

40.- F. Costa, B. Singer, J. Petr. 43, 1571, (2002).

41.- J. P. Davidson, M. A. Dungan, K. M. Ferguson, M. T. Colucci, Geol. 15, 443, (1987).

42.- J. P. Davidson, K. M. Ferguson, M. T. Colucci, M. A. Dungan, Cont. Min Petr. 100, 429- (1988)

43.- T. C. Feeley, M. A. Dungan, F. A. Frey, Cont. Min. Petr. 131, 393 , (1998).

44.- K.M. Ferguson, M.A. Dungan, J.P. Davidson, M.T. Colucci J. Petrol. 33, $1,(1992)$

45.- F. A. Frey, D. C. Gerlach, R. L. Hickey, L. López-Escobar, F. MunizagaVillavicencio, Cont. Min. Petr. 88, 133, (1984).

46.- D. C. Gerlach, F. A. Frey, H. Moreno Roa, L. López- Escobar, J. Petr. 29-2, 333, (1988).

47.- R. L. Hickey, F. A. Frey, D. C. Gerlach, L. López- Escobar J. Geophys. Res. 91, 5963, (1986).

48.- R. Hickey-Vargas, H. Moreno Roa, L. López- Escobar, F. A. Frey Cont Min. Petr. 103, 361, (1989).

49.- W. Hildreth, S. Moorbath, Cont. Min. Petr. 98, 455, (1988).

50.- L. López- Escobar, F. A. Frey,M. M. Vergara, Cont. Min. Petr. 63, 199, (1977).

51.- L. López- Escobar, M. A. Parada, H. Moreno, F. A. Frey, R. HickeyVargas, Rev. Geol. Chile 19, 211, (1992).

52.- L. López- Escobar, M. A. Parada, R. Hickey-Vargas, F. A. Frey, P. D. Kempton, H. Moreno Roa, Cont. Min. Petr. 119, 345, (1995).

53.- P. D. Jr. Noll, H. E. Newson, W. P. Leeman, J. G. Ryan, Geoch. Cosm. Acta 60, 587, (1996).

54.- O. Sigmarsson, M. Condomines, J. Morris, R. S. Harmon, Nature 346 , $163,(1990)$

55.- C. R. Stern, F. A. Frey, K. Futa, R. E. Zartman, Z. X. Peng, T. K. Kyser, Min. Petr. 104, 294, (1990).

56.- D. R. Tormey, R. Hickey-Vargas, F. A. Frey, L. López- Escobar, Geol. Soc. Am. Spec. Pap. 265, 57, (1991).

57.- M. M. Vergara, J. B. Muñoz Rev. Geol. Chile 17, 31, (1982).

58.- S. M. McLennan, Geoch. Geoph. Geos. 2, paper number 2000GC000109. (2001)

59.- A. Bollhöfer, K. J. R. Rosman, Geoch. Cosm. Acta 64, 3251, (2000).

60.- J. A. Naranjo, H. Moreno, C. Emparan, M. Murphy, Rev. Geol. Chile 20, 167, (1993).

61.- L. Chirinos, N. L. Rose, R. Urrutia, P. Munoz, F. Torrejon, L. Torres, F. Cruces, A. Araneda, C. Zaror, Environ. Pol. 141, 247, (2006).

62.- R. S. Harmon, B. A. Barreiro, S. Moorbath, J. Hoefs, P. W. Francis, S. Thorpe, B. Deruelle, J. McHugh, J. A. Viglino, J. Geol. Soc. London 141, 803 (1984).

63.- K. Notsu, L. López- Escobar, N. Onuma, Geoch. J. 21, 307, (1987).

64.- W. Siebel, W. B. W. Scnurr, K. Hahne, B. Kraemer, R. B. Trumbull, P. van den Bogaard, R. Emmermann, Chem. Geol. 171, 213, (2000).

65.- D. A. Hilton, K. Hammerschmidt, S. Teufel, H. Friedrichsen, Earth Planet. Sci. Lett. 120, 265, (1993). 
J. Chil. Chem. Soc., 53, № 3 (2008) 